\title{
Hydrolyzed collagen, modified starch and guar gum addition in turkey ham
}

\author{
Adição de colágeno hidrolisado, amido modificado e goma guar em presunto de peru
}

\author{
Rosa Cristina Prestes ${ }^{\mathrm{I}}$ Eliana Beleski Borba Carneiro ${ }^{\mathrm{II}}$ Ivo Mottin Demiate
}

\section{ABSTRACT}

The main problems observed in cooked hams are bad sliceability and excessive fluid loss after cooking. To reduce these problems the industry uses non-meat ingredients such as soy protein and carrageenan, but under Brazilian law, it is not allowed to add starch or modified starch in hams. Three ingredients were tested in the present research: modified starch ( 0 to $2.0 \%$ ), gum guar (0 to $0.30 \%$ ) and hydrolyzed collagen (0 to $2.0 \%$ ), following a $2^{3}$ full factorial design with five repetitions in the central point. The guar gum produced low resistance to reheating, however in losses by cooling, the results were adequate. The hydrolyzed collagen tested did not give satisfactory results, showing low acceptance due to formation of gel in the ham and high losses. The developed products were not different from the commercial product in relation to texture $(P>0.05)$. The formulation F6 (2.0\% of modified starch) was the one with the best results and greater acceptance as detected by the tasters. Based on the results obtained it seems appropriate to propose the legal permission of starch in ham or the creation of a new class of product in which starch addition would be allowed.

Key words: texture; factorial design, non-meat ingredients.

\section{RESUMO}

Os principais problemas observados em presuntos são a má fatiabilidade e a perda excessiva de líquidos após o cozimento. Para reduzir esses problemas, a indústria utiliza ingredientes não cárneos, tais como a proteína de soja e a carragena, porém, segundo a legislação brasileira, não é permitida a adição de amido ou amido modificado. Neste trabalho, foram testados três ingredientes, em presunto cozido de peru: amido modificado (0 a 2,0\%), goma guar (0 a $0,30 \%)$ e colágeno hidrolisado (0 a 2,0\%), seguindo um delineamento fatorial completo $2^{3} \mathrm{com}$ cinco repetições no ponto central. A goma guar apresentou baixa resistência ao reaquecimento, no entanto, nas perdas por resfriamento, os resultados foram adequados. O colágeno hidrolisado testado não proporcionou resultados satisfatórios, sendo que os produtos apresentaram baixa aceitação devido à formação de gel e a maiores perdas. Os produtos desenvolvidos não foram diferentes do produto comercial em relação à textura $(P>0,05)$. A formulação $F 6$ (2,0\% amido modificado) foi a que obteve os melhores resultados e a maior aceitação por parte dos julgadores. Com base nos resultados obtidos, parece-nos adequado propor a permissão legal de amido em presunto ou a criação de uma nova classe de produto para a qual se permita a utilização deste ingrediente.

Palavras-chave: textura, planejamento fatorial, ingredientes não cárneos.

\section{INTRODUCTION}

Several ingredients are used with the main objectives of reducing cooking losses, increasing shelflife, reducing costs of the formulation, increasing the brine retention, improving nutritional value and sliceability of the meat products (MITTAL \& USBORNE, 2006, BARBUT, 2002). The most used ingredients are gums and soy protein that favor the formation of a continuous matrix during cooking, modifying the viscosity, mobility and other properties of the aqueous phase, influencing the rheological properties (BARRERA et al., 2002).

\footnotetext{
'Departamento de Tecnologia e Ciência de Alimentos (DTCA), Centro de Ciências Rurais (CCR), Universidade Federal de Santa Maria (UFSM), 97105-900, Santa Maria, RS, Brasil. E-mail: rosacrisprestes@hotmail.com. Autor para correspondência.

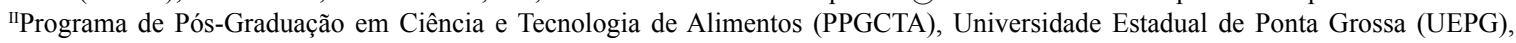
Ponta Grossa, PR, Brasil.
} 
SCHILLING et al. (2003) used native collagen (up to $3.0 \% \mathrm{~m} / \mathrm{m}$ ) in hams made with PSE meat and noted improved functionality, decrease in cooking losses, reduced costs of development and there was no change in color, but the use of collagen did not prevent loss of fluids that reached $10.95 \%$ in final product. DAIGLE et al. (2005) studied the effect of adding $1.5 \%$ collagen in turkey breast meat and obtained $9.45 \%$ of losses in cooking and $3.01 \%$ of syneresis $\left(48 \mathrm{~h}\right.$ at $\left.4^{\circ} \mathrm{C}\right)$. The addition of collagen increased the protein content in the final product and reduced syneresis. The values of color parameters were not affected. PRABHU et al. (2004) suggested that increased levels of collagen increased the firmness of the product.

In Brazil the commercial use of starches in cooked hams is not allowed, although in the USA there is the possibility of applying until $2.0 \%$ in a kind of ham that must be labeled as "ham water added" (USA, 1999). The guar gum presents high molecular weight, is heat stable and forms colloidal dispersions in water, producing high viscosity. LIGUTOM et al. (1999) evaluated the addition of guar gum in meat balls and found out that there was no effect in the appearance, but it had effect on the taste and acceptability of the product. In the present work a $2^{3}$ full factorial experimental design with five repetitions in the central point was used with the objective of studying the effects of adding hydrolyzed collagen, modified starch and guar gum in the chemical composition, physical and sensory characteristics of turkey ham.

\section{MATERIALS AND METHODS}

The hams were produced by employing deboned turkey legs in the laboratories of the Perdigão Agroindustrial S/A. The ingredients used were: (HC) hydrolyzed collagen (10,000 $\mathrm{Da}$, derived from bovine skin), (MS) modified food starch (hydroxypropyl distarch phosphate derived from waxy maize) and (GG) guar gum (extract from the seed of the legume plant Cyamopsis tetragonolobus). The raw material was cut in two pre-discs of the grinder (Saydmam ${ }^{\circledR}$ ) and then the brine was added of $77.0 \%$ of water, $9.45 \%$ of sodium chloride, $1.75 \%$ of sodium tripolyphosphate, $1.75 \%$ of sucrose, $1.05 \%$ of curing salt (sodium nitrite and sodium nitrate), $0.88 \%$ of concentrate condiment for ham and $0.18 \%$ of antioxidant. The addition of HC, MS and GG was carried out directly in the mass before tumbling (formulations as show in table 1). A 30L capacity Inject $\mathrm{Star}^{\mathbb{R}}$ Tumbler was used (injection of $40 \%$ ). The step of tumbling took four hours, under refrigeration $\left(0\right.$ to $\left.4^{\circ} \mathrm{C}\right)$ and vaccum of $70 \%$ with rotation of around $12 \mathrm{rpm}$.
Table 1 - Formulations tested based on $2^{3}$ factorial design (real values and coded).

\begin{tabular}{|c|c|c|c|}
\hline \multirow{2}{*}{ Formulations } & \multicolumn{3}{|c|}{---------Ingredients tested*-------- } \\
\hline & MS & $\mathrm{HC}$ & GG \\
\hline \multirow[t]{2}{*}{ F1 } & $2.0 \%$ & $2.0 \%$ & $0.30 \%$ \\
\hline & $(+1)$ & $(+1)$ & $(+1)$ \\
\hline \multirow[t]{2}{*}{$\mathrm{F} 2$} & $2.0 \%$ & $0.0 \%$ & $0.0 \%$ \\
\hline & $(+1)$ & $(-1)$ & $(-1)$ \\
\hline \multirow[t]{2}{*}{ F3 } & $0.0 \%$ & $2.0 \%$ & $0.30 \%$ \\
\hline & $(-1)$ & $(+1)$ & $(+1)$ \\
\hline \multirow[t]{2}{*}{$\mathrm{F} 4$} & $0.0 \%$ & $0.0 \%$ & $0.30 \%$ \\
\hline & $(-1)$ & $(-1)$ & $(+1)$ \\
\hline \multirow[t]{2}{*}{ F5 } & $2.0 \%$ & $2.0 \%$ & $0.0 \%$ \\
\hline & $(+1)$ & $(+1)$ & $(-1)$ \\
\hline \multirow[t]{2}{*}{ F6 } & $2.0 \%$ & $0.0 \%$ & $0.0 \%$ \\
\hline & $(+1)$ & $(-1)$ & $(-1)$ \\
\hline \multirow[t]{2}{*}{ F7 } & $0.0 \%$ & $2.0 \%$ & $0.0 \%$ \\
\hline & $(-1)$ & $(+1)$ & $(-1)$ \\
\hline \multirow[t]{2}{*}{ F8 } & $0.0 \%$ & $0.0 \%$ & $0.0 \%$ \\
\hline & $(-1)$ & $(-1)$ & $(-1)$ \\
\hline \multirow[t]{2}{*}{$\mathrm{CP} * *$} & $1.0 \%$ & $1.0 \%$ & $0.15 \%$ \\
\hline & $(0)$ & $(0)$ & (0) \\
\hline
\end{tabular}

* MS: modified starch, HC: hydrolyzed collagen and GG: guar gum.

** CP: central point corresponds to formulations F9, F10, F11, F12 and F13.

After this period the pieces were filled in a stuffer into non-thermoshrinkable polyamide casings (thickness of $13 \mu \mathrm{m}$ ), clipping and moulded in $2.5 \mathrm{~kg}$ stainless steel moulds and left for a period of 18 hours. Cooking was done in an oven until the internal temperature reached $72^{\circ} \mathrm{C}$ and the samples were kept refrigerated $\left(7^{\circ} \mathrm{C}\right)$. The concentrations of MS and $\mathrm{HC}$ followed the producers' recommendations (until 2.0\%). The GG was used in the maximum amount allowed by the Brazilian legislation, of $0.3 \%$ (BRASIL, 1998).

Proximate analysis, potential of hydrogen $(\mathrm{pH})$ and water holding capacity (WHC)

The analyses of moisture, mineral residue, proteins, lipids and $\mathrm{pH}$ were made in duplicate following the official methods (BRASIL, 2005). The WHC was evaluated in triplicate using the adapted method of OCKERMAN \& ORGANISCIAK (1978) where the sampling of $3.0 \mathrm{~cm}$ diameter and $2.5 \mathrm{~cm}$ height pieces that were weighed and compressed (50\%) using a plate of $3.0 \mathrm{~kg}$ for 15 minutes at room temperature $\left(22^{\circ} \mathrm{C}\right)$. After the pressing period the samples were dried with paper towels and weighed again. The water holding in percentage was calculated by the difference of weight. 
Water activity $\left(\mathrm{A}_{\mathrm{w}}\right)$, purge loss and freeze-thaw stability The $\mathrm{A}_{\mathrm{w}}$ was measured by using an Aqualab $^{\circledR}$ (Decagon Device, Inc.) at $20^{\circ} \mathrm{C}$ in triplicate. For purge, the ham samples were stored refrigerated for 10 days, individually weighed before and after opening and drying the product and the packages. The purge loss was calculated by the weight difference. The freezestability was evaluated using the methodology adapted from LEE et al. (2002). The samples were cut into pieces $\left(\sim 1 \mathrm{~cm}^{3}\right)$ and were individually weighed, packed in sealed plastic bags and frozen $\left(-18^{\circ} \mathrm{C}\right)$. After 24 hours the samples were thawed at room temperature $\left(\sim 22^{\circ} \mathrm{C}\right)$ for four hours, removed from the bags and packed into a $12.5 \mathrm{~cm}$ round filter paper. Then, the material was pressed between two glass plates using a $2.0 \mathrm{~kg}$ weight for five minutes and after the samples were weighed.

Reheating losses, texture analysis and color

The reheating was calculated by the difference of weight and this analysis was made in duplicate using methodology from HACHMEISTER \& HERALD (1998). The TA.XT2i ${ }^{\circledR}$ (Stable Micro Systems $^{\circledR}$ ) was employed for evaluating the texture profile. The samples $(1.5 \times 1.5 \times 2.0 \mathrm{~cm})$ were compressed to $66.7 \%$ of their original height using the $\mathrm{P} 25$ crosshead $(25 \mathrm{~mm})$ and data was collected by the software Texture Expert V1.19 (Stable Micro Systems ${ }^{\circledR}$ ). The maximum values of compression peaks are presented in Newton (N). The probe used to evaluate the shear strength of the samples of turkey ham slices $(1.5 \times 1.5 \times 4.0 \mathrm{~cm})$ was the Warner-Bratzler Blade (HDP / BS). For these analyses were also performed 10 repetitions. The color coordinates $\mathrm{L}^{*}$ (luminosity), a* (redness) and $\mathrm{b}^{*}$ (yellowness) were obtained by using a Minolta ${ }^{\circledR}$, model CR400, light D65 colorimeter, calibrated with a white standard $(Y=93, x=0.3136$ e $y=0.3321)$. Six repetitions were made.

Syneresis and sensory analysis

Ten cubes $(2.0 \mathrm{~cm}$ of side) were vaccum packed and stored under refrigeration and after two days these samples were left for two hours at room temperature for simulating bad storing conditions. After these two hours the smaples were put back in the refrigerator. After a seven-day period of repetition of the described proceeding, the package was opened and the cubes were dried and weighed. The syneresis percentage was calculated by weight difference and in duplicate. In the sensory analysis the panelists were asked to prove the samples comparing them with the standard by using a scale (1-better than, 2-equal e 3worse than) and in a second step they evaluated the degree of difference betweeen the coded sample and the standard, using a scale (1-none to 5-extreme). For this step, 20 judges were made with non trained panelists for each analysis. In another test 15 non trained panelists evaluated general attributes, as appearence, color, odor, flavor and texture. The samples were cut in cubes and coded. For evaluating the attributes the panelists used a quality scale of five points with scores varying from 1-very bad to 5-excelent (ABNT, 1998).

\section{Statistical analysis}

To reduce the number of experiments what would require much time and would be expensive, a $2^{3}$ full factorial design with five replicates at the central point was performed. This enables the implementation and the approach of statistical inference, as it allows the calculation of residue and therefore the standard errors and interval estimates. Tests at the central point provide useful information about the behavior of responses and highlight the quality of the repeatability of the process (RODRIGUES \& IEMMA, 2009). The evaluation consisted of: Analysis of Variance (ANOVA), Tukey's test (significance level of 95\%) which calculated the effects, evaluation of the regression coefficient by testing F (Fischer-Snedecor) and if the model was appropriate it was considered predictor for the construction of response surfaces which allowed the visualization. Only models that had appropriate regression coefficient allowing the graphical representation (response surface) are presented. Data evaluation was performed using the Statistica ${ }^{\circledR} 5.0$ (StatSoft Inc.) and Microsoft ${ }^{\circledR}$ Excel 2003 (Microsoft Co.) softwares.

\section{RESULTS AND DISCUSSION}

Proximate composition, $\mathrm{pH}$ and $\mathrm{WHC}$

In table 2 it is possible to note that there was significant difference for the moisture and lipid values $(\mathrm{P}<0.05)$, but this was not observed for the protein and mineral residue levels content $(\mathrm{P}>0.05)$. The sample produced with the studied ingredients in the maximum levels (F1-2.0\% MS, $2.0 \% \mathrm{HC}$ and $0.3 \% \mathrm{GG}$ ) was not the one with the highest brine retention. The F3 (2.0\% HC and $0.3 \% \mathrm{GG})$ presented the lower brine retention and this was probably related with the excessive liberation during cooking. Some samples (F2, F4, F6 e F8) do not fit the Brazilian Identity and Quality Standard for Ham (Brasil, 2000) due to the fact that the protein levels were lower than $14.0 \%$. PEARSON \& TAUBER (1984) mentioned that in general the physical and chemical composition of ham has an average moisture content of $71.0 \%, 15.0 \%$ protein, $9.0 \%$ fat, $\mathrm{pH}$ 
Table 2 - Proximate analysis (moisture, protein, lipids and mineral residue), potential hydrogen (pH), water hoding capacity (WHC) and water activity (Aw) for samples of developed turkey ham.

\begin{tabular}{|c|c|c|c|c|c|c|c|}
\hline Formulations* & Moisture (\%) & Protein $(\%)$ & Lipids (\%) & Mineral Residue (\%) & $\mathrm{pH}$ & WHC (\%) & Aw \\
\hline F1 & $75.16^{\mathrm{ab}}$ & $15.36^{\mathrm{a}}$ & $0.93^{\mathrm{ab}}$ & $4.18^{\mathrm{a}}$ & $6.57^{\mathrm{a}}$ & $96.94^{\mathrm{b}}$ & $0.845^{\mathrm{a}}$ \\
\hline $\mathrm{F} 2$ & $76.91^{\mathrm{b}}$ & $13.34^{\mathrm{a}}$ & $0.69^{\mathrm{a}}$ & $3.98^{\mathrm{a}}$ & $6.64^{\mathrm{a}}$ & $97.01^{\mathrm{b}}$ & $0.855^{\mathrm{a}}$ \\
\hline F3 & $73.61^{\mathrm{a}}$ & $15.09^{\mathrm{a}}$ & $1.25^{\mathrm{abc}}$ & $4.06^{\mathrm{a}}$ & $6.61^{\mathrm{a}}$ & $97.71^{\mathrm{b}}$ & $0.850^{\mathrm{a}}$ \\
\hline F4 & $77.40^{\mathrm{b}}$ & $13.51^{\mathrm{a}}$ & $1.31^{\mathrm{abcd}}$ & $3.92^{\mathrm{a}}$ & $6.66^{\mathrm{a}}$ & $92.83^{\mathrm{a}}$ & $0.850^{\mathrm{a}}$ \\
\hline F5 & $74.80^{\mathrm{ab}}$ & $14.15^{\mathrm{a}}$ & $0.70^{\mathrm{a}}$ & $4.12^{\mathrm{a}}$ & $6.52^{\mathrm{a}}$ & $97.74^{\mathrm{b}}$ & $0.845^{\mathrm{a}}$ \\
\hline F6 & $77.13^{b}$ & $12.72^{\mathrm{a}}$ & $0.80^{\mathrm{ab}}$ & $2.64^{\mathrm{a}}$ & $6.69^{\mathrm{a}}$ & $98.02^{\mathrm{b}}$ & $0.850^{\mathrm{a}}$ \\
\hline F7 & $75.31^{\mathrm{ab}}$ & $14.03^{\mathrm{a}}$ & $1.86^{\mathrm{cde}}$ & $4.06^{\mathrm{a}}$ & $6.55^{\mathrm{a}}$ & $96.63^{b}$ & $0.850^{\mathrm{a}}$ \\
\hline F8 & $77.53^{b}$ & $13.51^{\mathrm{a}}$ & $2.23^{\mathrm{e}}$ & $4.11^{\mathrm{a}}$ & $6.58^{\mathrm{a}}$ & $97.15^{b}$ & $0.850^{\mathrm{a}}$ \\
\hline $\mathrm{CP}$ & $76.76^{\mathrm{b}}$ & $14.18^{\mathrm{a}}$ & $1.18^{\mathrm{abc}}$ & $4.11^{\mathrm{a}}$ & $6.61^{\mathrm{a}}$ & $98,19^{\mathrm{b}}$ & $0.857^{\mathrm{a}}$ \\
\hline
\end{tabular}

a,b Means with different letters in the columns differ significantly $(\mathrm{P}<0.05)$.

* F1 (2.0\% MS, 2.0\% HC and 0.30\% GG), F2 (2.0\% MS and 0.30\% GG), F3 (2.0\% HC and $0.30 \%$ GG), F4 (0.30\% GG), F5 (2.0\% HC and $2.0 \% \mathrm{MS}), \mathrm{F} 6(2.0 \% \mathrm{MS}), \mathrm{F} 7(2.0 \% \mathrm{HC}), \mathrm{F} 8(0.0 \% \mathrm{MS}, 0.0 \% \mathrm{HC}$ and $0.0 \% \mathrm{GG})$ and $\mathrm{CP}(1.0 \% \mathrm{MS}, 1.0 \% \mathrm{HC}$ and $0.15 \% \mathrm{de} \mathrm{GG})$.

between 5.9 and 6.1. There are reports of increase in protein level when collagen was added in levels higher than $3.63 \%$ in meat emulsions. The lipid concentrations are different from those values of 2.0 to $3.2 \%$ reported (BARBUT, 2002). The low lipid levels found may be associated with the utilization of meat from turkey legs. The samples did not present differences in the $\mathrm{pH}$ values $(\mathrm{P}>0.05)$, as shown in the table 2 . The values are in accordance with 6.59 to 6.65 reported in other study (PEDROSO \& DEMIATE, 2008). According to OLIVO $\&$ SHIMOKOMAKI (2001) small variations in $\mathrm{pH}$ are acceptable for this kind of processed meat. There was significant difference in the WHC among the samples $(\mathrm{P}<0.05)$ (Table 2). The formulation $\mathrm{F} 4(0.3 \% \mathrm{GG})$ presented the lowest WHC showing that the ingredients were not capable of improving brine retention. The observed results demonstrate the ability of the tested ingredients to assist in moisture retention in the protein matrix.

$A_{w}$, purge loss and freeze-thaw stability

As shown in table 2, the values found for $A_{w}$ were lower than the range 0.96 to 0.98 reported by PEARSON \& TAUBER (1984). This is a good result from the microbiological point of view as the addition of the ingredients reduced the available water contributing to a higher shelf life. In table 3 the purge loss is shown and there were significant differences among the samples $(\mathrm{P}<0.05)$. The lowest value was found for the F6 $(2.0 \% \mathrm{MS})$ formulation whereas the highest was for the F7 (2.0\% HC). PEDROSO \& DEMIATE (2008) found 0.91 to $8.18 \%$ for purge loss in turkey ham. In the same manner, the results showed lower losses for the formulations with $2.0 \%(\mathrm{~m} / \mathrm{m})$ of

Table 3 - Results of purge loss (PL), freeze-thaw stability (FS), reheating losses (RL), cutting forces (CF), coordinates a* (redness), L* (luminosity), b* (yellowness), compression (COMP) and syneresis (SY) for developed samples of turkey ham.

\begin{tabular}{|c|c|c|c|c|c|c|c|c|c|}
\hline Formulations* & PL (\%) & FS (\%) & RL (\%) & $\mathrm{CF}(\mathrm{N})$ & $a^{*}$ & $\mathrm{~L}^{*}$ & $b^{*}$ & $\operatorname{COMP}(\mathrm{N})$ & SY $(\%)$ \\
\hline F1 & $0.40^{\mathrm{ab}}$ & $5.16^{\mathrm{a}}$ & $12.90^{\mathrm{a}}$ & $7.61^{\mathrm{a}}$ & $13.34^{\mathrm{a}}$ & $62.90^{\mathrm{ab}}$ & $4.39^{\mathrm{ab}}$ & $16.58^{\mathrm{a}}$ & $1.04^{\mathrm{a}}$ \\
\hline $\mathrm{F} 2$ & $0.55^{\mathrm{bc}}$ & $4.90^{\mathrm{a}}$ & $13.53^{\mathrm{ab}}$ & $9.32^{\mathrm{ab}}$ & $13.26^{\mathrm{a}}$ & $61.62^{\mathrm{ab}}$ & $4.54^{\mathrm{ab}}$ & $23.51^{\mathrm{abc}}$ & $1.84^{\mathrm{ab}}$ \\
\hline F3 & $2.64^{\mathrm{h}}$ & $4.80^{\mathrm{a}}$ & $21.60^{\mathrm{bc}}$ & $8.55^{\mathrm{ab}}$ & $13.53^{\mathrm{a}}$ & $62.91^{\mathrm{ab}}$ & $4.57^{\mathrm{ab}}$ & $22.44^{\mathrm{ab}}$ & $2.71^{\mathrm{abcd}}$ \\
\hline F4 & $0.88^{\mathrm{d}}$ & $5.59^{\mathrm{a}}$ & $26.41^{\mathrm{c}}$ & $8.18^{\mathrm{ab}}$ & $14.61^{\mathrm{a}}$ & $60.95^{\mathrm{a}}$ & $5.17^{\mathrm{b}}$ & $27.93^{\mathrm{bcd}}$ & $4.72^{\mathrm{cd}}$ \\
\hline F5 & $1.75^{\mathrm{g}}$ & $4.47^{\mathrm{a}}$ & $18.94^{\mathrm{abc}}$ & $8.94^{\mathrm{ab}}$ & $12.62^{\mathrm{a}}$ & $63.75^{\mathrm{ab}}$ & $4.56^{\mathrm{ab}}$ & $30.65^{\text {cde }}$ & $1.92^{\mathrm{ab}}$ \\
\hline F6 & $0.32^{\mathrm{a}}$ & $4.00^{\mathrm{a}}$ & $13.72^{\mathrm{ab}}$ & $9.28^{\mathrm{ab}}$ & $13.72^{\mathrm{a}}$ & $61.55^{\mathrm{ab}}$ & $3.50^{\mathrm{a}}$ & $49.55^{\mathrm{g}}$ & $2.11^{\mathrm{ab}}$ \\
\hline F7 & $3.43^{\mathrm{i}}$ & $10.02^{b}$ & $24.96^{\mathrm{c}}$ & $9.77^{\mathrm{ab}}$ & $14.10^{\mathrm{a}}$ & $63.48^{\mathrm{ab}}$ & $4.68^{b}$ & $38.11^{\text {ef }}$ & $3.72^{\mathrm{bcd}}$ \\
\hline F8 & $1.61^{\mathrm{fg}}$ & $10.18^{b}$ & $20.57^{\mathrm{abc}}$ & $11.64^{\mathrm{b}}$ & $13.75^{\mathrm{a}}$ & $64.35^{\mathrm{ab}}$ & $4.21^{\mathrm{ab}}$ & $61.51^{\mathrm{h}}$ & $5.13^{d}$ \\
\hline $\mathrm{CP}$ & $0.92^{\mathrm{d}}$ & $4.32^{\mathrm{a}}$ & $15.41^{\mathrm{ab}}$ & $8.44^{\mathrm{ab}}$ & $13.71^{\mathrm{a}}$ & $62.64^{\mathrm{ab}}$ & $4.45^{\mathrm{ab}}$ & $31.71^{\mathrm{de}}$ & $1.68^{\mathrm{ab}}$ \\
\hline
\end{tabular}

\footnotetext{
${ }^{\mathrm{a}, \mathrm{b}}$ Means with different letters in the columns differ significantly $(\mathrm{P}<0.05)$.

* F1 (2.0\% MS, 2.0\% HC and 0.30\% GG), F2 (2.0\% MS and 0.30\% GG), F3 (2.0\% HC and 0.30\% GG), F4 (0.30\% GG), F5 (2.0\% HC and $2.0 \% \mathrm{MS}), \mathrm{F} 6(2.0 \% \mathrm{MS}), \mathrm{F} 7(2.0 \% \mathrm{HC}), \mathrm{F} 8(0.0 \% \mathrm{MS}, 0.0 \% \mathrm{HC}$ and $0.0 \% \mathrm{GG})$ and $\mathrm{CP}(1.0 \% \mathrm{MS}, 1.0 \% \mathrm{HC}$ and $0.15 \% \mathrm{de} \mathrm{GG})$
} 
MS confirming the ownership of this polysaccharide to interact with protein matrix and retain water in the structure. The samples frozen and thawed presented significant differences in their fluid losses (Table 3). The formulation F6 (2.0\% MS) had the lowest loss. The model was used in the construction of response surfaces $\left(\mathrm{R}^{2}=81 \%\right)$, allowing the visualization of the behavior of the percentage of losses by freeze-thawing of hams developed in light of significant variables (Figure 1). Freezing is not recommended for cooked hams, but due to the increasing market of convenient frozen dishes, the meat industry is interested in improving the quality of cooked hams that could be frozen without loosing quality.

Reheating losses, texture analysis and color

There was significant difference among the developed samples $(\mathrm{P}<0.05)$ and the F1 $(2.0 \% \mathrm{MS}, 2.0 \%$ $\mathrm{HC}$ and $0.30 \% \mathrm{GG}$ ) formulation, that included the three studied ingredients, and presented the lowest loss (Table 3). The higher concentrations of MS resulted in lower reheating losses; this result is in accordance with HACHMEISTER \& HERALD (1998). Although it was possible to observe that the higher losses occurred with higher concentrations of HC due to low stability to heat this protein (KARIM \& BHAT, 2008).

The results for compression and cutting forces are shown significant difference $(\mathrm{P}<0.05)$ (Table 3 ). The higher cutting force and higher resistence to compression value was detected for sample F8 $(0.0 \%$ MS, $0.0 \% \mathrm{HC}$ and $0.0 \% \mathrm{GG}$ ) indicates that the added ingredients contributed to higher water retention inside the product that became softer. It is not in accordance with the results of LIGUTOM et al. (1999) that found significant effect of collagen addition for the cutting force that increased with increasing concentrations of the ingredient. The results for the parameter compression showed that F1 $(2.0 \% \mathrm{MS}, 2.0 \% \mathrm{HC}$ and $0.3 \% \mathrm{GG}$ ) presented the lower value and this result should be related with the higher amount of retained water/brine inside the sample. These results agree with SCHILLING etal. (2003) and DAIGLE et al. (2005) where products with higher WHC had consequently softer texture and higher resistance to compression. For the values $L^{*}$ and $b^{*}$ there were significant differences $(\mathrm{P}<0.05)$ but not for $\mathrm{a}^{*}(\mathrm{P}>0.05)$ (Table 3$)$. The lowest $\mathrm{L}^{*}$ was found for sample F4 $(0.3 \% \mathrm{GG})$ which showed that the use of GG resulted in a more opaque product. For the $b^{*}$ value, the sample containing MS (F6) was the one that had the lowest value. The addition of GG resulted in a more opaque color (lower $\mathrm{L}^{*}$ and smaller $b^{*}$ ) than those of the formulations added of MS. This result can be explained by the use of MS that is clearer than GG that is obtained from the ground endosperm of seeds and can be explained by a reduction in the concentration of myoglobin in meat (YOUSSEF \& BARBUT, 2011). However, these products are often less accepted by consumers.

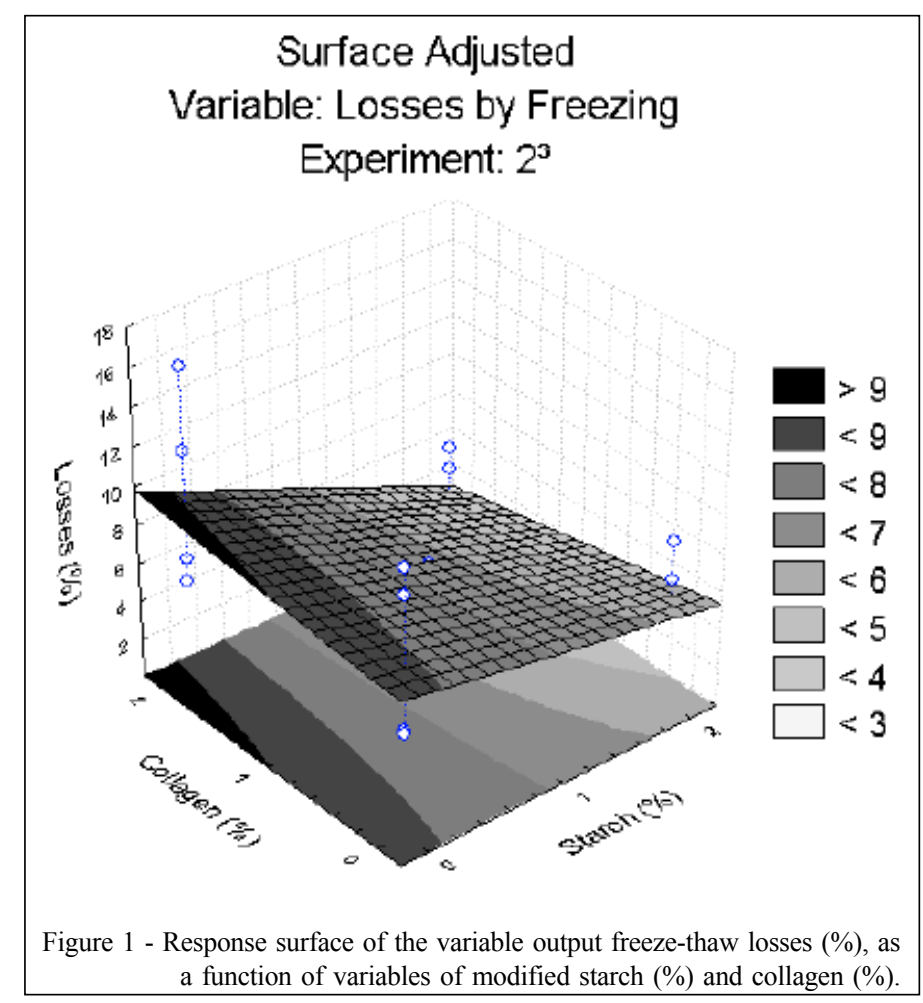

Ciência Rural, v.42, n.7, jul, 2012. 
Syneresis and sensory analysis

The syneresis was evaluated in order to simulate bad storage conditions and the worst results were found for the F8 $(0.0 \% \mathrm{MS}, 0.0 \% \mathrm{HC}$ and $0.0 \%$ GG) sample (Table 3). Significant differences were observed $(\mathrm{P}<0.05)$ and as was expected, the sample $\mathrm{F} 1$ (2.0\% MS, $2.0 \% \mathrm{HC}$ and $0.3 \% \mathrm{GG}$ ) presented the lower syneresis. Other researchers found syneresis values of $3.29 \%$, after a four-week storage period and using $2.0 \%$ collagen that can be considered close to the result found in the present research, of $3.72 \%$. The assessment is important because syneresis of hams sliced at the point of sale is undesirable and can cause weight loss (PEDROSO, 2008) and also negatively affects the sensory acceptance of the product by consumers. For this important aspect the formulations F1, F2, F5, F6 and CP showed results lower than those found in the literature. In the sensory analysis the samples were not different from the commercial sample $(\mathrm{P}>0.05)$, considered as a commercial standard. When the panelists were asked about the degree of difference of the samples, the average value from the scale was 3 , indicating a regular difference among the samples. The results of the profile of characteristics indicated significant differences $(\mathrm{P}<0.05)$ among the formulations relative to texture, taste, color and appearance but there was no difference $(\mathrm{P}>0.05)$ for odor. The sample F6 (2.0\% MS) was considered the best with the higher grades for all the tested attributes. The grades assigned on a scale of 1 to 5 ( 1 - very bad to 5 - excellent) were: $4.13,4.27,3.73,4.00$ and 4.27 for texture, flavor, odor, color and appearance, respectively.

\section{CONCLUSION}

The formulations with hydrolyzed collagen and guar gum underperformed the modified starch but further studies are necessary to improve the performance of these ingredients. The formulation with solely modified starch (F6) showed the best results and had the best acceptability by the panelists. Formulations with modified starch were related with the best results both considering the physicochemical and the sensory analyses. Finally the results allow a suggestion of legal permission in Brazil for adding starch in hams or the creation of a new class of product in which this addition is regulated.

\section{BIOETHICS AND BIOSSECURITY COMMITTEE APPROVAL}

The evaluation was performed with employees (panelists) who participated in tastings routine of the company and they were duly qualified and authorized to participate (adequate health and spontaneity). The evaluations were performed with their consent and release by the company (Department of Research and Development). Before testing the developed products were evaluated according to the microbiological standards of the Brazilian law and all were suitable for consumption.

\section{REFERENCES}

ABNT. ASSOCIAÇÃO BRASILEIRA DE NORMAS TÉCNICAS. NBR 14141: escalas utilizadas em análise sensorial de alimentos e bebidas. Rio de Janeiro, 1998. 3p.

BARBUT, S. Poultry products processing: an industry guide. New York: CRC, 2002. 548p.

BARRERA, A.M. et al. Effect of pectins on the gelling properties of surimi from silver carp. Food Hydrocolloids, v.16, p.441447, 2002. Available from: <http://www.sciencedirect.com/science/ article/pii/S0268005X01001217>. Accessed: Nov 22, 2007. doi: http://dx.doi.org/10.1016/ S0268-005x(01)00121-7.

BRASIL, Ministério da Saúde. Agência Nacional de Vigilância Sanitária. Métodos físico-químicos para análises de alimentos. Brasília: Agência Nacional de Vigilância Sanitária, 2005. 1018 p.

BRASIL, Ministério da Agricultura. Regulamento técnico de identidade e qualidade de presunto. Brasília: MAP A, 2000. p.1-4. (Anexo IV).

BRASIL, Ministério da Saúde. Portaria n.1004 de 11 de dezembro de 1998. Atribuição de função dos aditivos e seus limites máximos de uso para a categoria - Carnes e produtos Cárneos. Brasília: Ministério da Saúde, 1998. Available from: <http://www.anvisa.gov.br/alimentos>. Accessed: Jan 05, 2007.

DAIGLE, S.P. et al. PSE-like turkey breast enhancement through adjunct incorporation in a chunked and formed deli roll. Meat Science, v.69, p.319-324, 2005. Available from: <http:// www.sciencedirect.com/science/article/pii/ S0309174004002086>. Accessed: Nov 22, 2007. doi: http:// dx.doi.org/10.1016/ j.meatsci.2004.08.001.

HACHMEISTER, K.A.; HERALD, T.J. Thermal and reological properties and textural atributes of reduced-fat turkey batters. Poultry Science, v.77, p.632-638, 1998.

KARIM, A.A.; BHAT, R. Gelatin alternatives for the food industry: recent developments, challegens and prospects. Food Science e Technology, v.19, p.644-656, 2008. Available from: $<\mathrm{http}$ ://www.sciencedirect.com/science/article/pii/ S0924224408002252>. Accessed: Feb 12, 2009. doi: 10.1016/ j.tifs.2008.08.001.

LEE, M.H. et al. Freeze-thaw stabilization of sweet potato starch gel by polysaccharide gums. Food Hydrocolloids, v.16, p.345352, 2002. Available from: <http://www.sciencedirect.com/science/ article/pii/S0268005X01001072>. Accessed: Nov 22, 2007. doi: http://dx.doi.org/10.1016/ S0268-005X(01)00107-2.

LIGUTOM, H. et al. Use of seed gums in low-fat ground pork: effect on physical and sensory characteristics. Meat Science, v.70, p.691-698, 1999. Available from: <http:// 
www.sciencedirect.com/science/article/pii/S0002822399004897>. Accessed: Nov 15, 2009. doi: http://dx.doi.org/10.1016/ S00028223(99)00489-7.

MITTAL, G.S.; USBORNE, W.R. Meat emulsion functionality related to fat-protein ratio and selected dairy and cereal products. Meat Science, v.18, p.1-21, 2006. Available from: <http:// ww w. sciencedirect.com/science/article/pi i/ 030917408690063X>. Accessed: Feb 11, 2007. doi: http:// dx.doi.org/10.1016/0309-1740(86)90063-X.

OCKERMAN, H.W.; ORGANISCIAK, C.S. Difusion of curing brine in tumbled and non-tumbled porcine muscle tissue. Journal Food Protein, v.41, p.178-181, 1978

OLIVO, R.; SHIMOKOMAKI, M. Carnes: no caminho da pesquisa. Cocal do Sul: Imprint, 2001. 155p.

PEARSON, A.M.; TAUBER, F.W. Composition and nutritive value of materials and processed meats. Local: AVI, 1984. 367p.

PEDROSO, R.A.; DEMIATE, I.M. Avaliação da influência de amido e carragena nas características físico-químicas e sensoriais de presunto cozido de peru. Ciência e Tecnologia de Alimentos, v.28, p.24-31, 2008. Available from: <http:// www.scielo.br/scielo.php?script $=$ sci arttext\&pid $=\mathrm{S} 0101$ $20612008000100005 \& \operatorname{lng}=\mathrm{pt} \& \mathrm{nrm}=\mathrm{iso} \& \mathrm{t} \operatorname{lng}=\mathrm{pt}>$. Accessed Nov 11, 2008. doi: 1590/S0101-20612008000100005.
PRABHU, G.A. et al. Utilization of pork collagen protein in emulsified and whole muscle meat products. Journal of Food Chemistry and Toxicology, v.69, n.5, p.388-392, 2004.

RODRIGUES, M.I.; IEMMA, A.F. Planejamento de experimentos e otimização de processos. Campinas: Casa do Pão, 2009. 326p.

SCHILLING, M.W. et al. Utilization of pork collagen for functionality improvement of boneless cured ham manufactured from pale, soft, and exudative pork. Meat Science, v.65, p.547553, 2003. Available from: <http://www.sciencedirect.com/science/ article/pii/S0309174002002474>. Accessed: Oct 12, 2008. doi: http://dx.doi.org/10.1016/ S0309-1740(02) 00247-4.

USA, Federal Register. Use of soy protein concentrate, modified food stacrch and Carrageenan as binders in certain meat products. Washington DC, v.64, n.99, 1999.

YOUSSEF, M.K.; BARBUT, S. Effects of two types of soy protein isolates, native and preheated whey protein isolates on emulsified meat batters prepared at different protein levels. Meat Science, v.87, p.54-80, 2011. Available from: $<$ http:// ww w. sciencedirect.com/science/article/pi i/ S0309174010003335>. Accessed: Feb 12, 2011. doi: http:// dx.doi.org/10.1016/j.meatsci.2010.09.002 